\title{
The Involvement of Protein Kinases in the Cardioprotective Effect of Chronic Hypoxia
}

\author{
Natalia V. NARYZHNAYA ${ }^{1}$, Hui-Jie MA², Leonid N. MASLOV ${ }^{1}$ \\ ${ }^{1}$ Cardiology Research Institute, Tomsk National Research Medical Center, Russian Academy of \\ Sciences, Tomsk, Russia, ${ }^{2}$ Hebei Medical University, Shijiazhuang, Hebei Province, P.R. China
}

Received January 21, 2020

Accepted September 29, 2020

Epub Ahead of Print November 2, 2020

\section{Summary}

The purpose of this review is to analyze the involvement of protein kinases in the cardioprotective mechanism induced by chronic hypoxia. It has been reported that chronic intermittent hypoxia contributes to increased expression of the following kinases in the myocardium: PKC $, \mathrm{PKCa}, \mathrm{p}-\mathrm{PKC} \varepsilon, \mathrm{p}-\mathrm{PKCa}, \mathrm{AMPK}$, p-AMPK, CaMKII, p-ERK1/2, p-Akt, PI3-kinase, p-p38, HK-1, and HK-2; whereas, chronic normobaric hypoxia promotes increased expression of the following kinases in the myocardium: $\mathrm{PKC} \varepsilon$, PKCBII, PKCn, CaMKII, p-ERK1/2, p-Akt, p-p38, HK-1, and HK-2. However, $\mathrm{CNH}$ does not promote enhanced expression of the AMPK and JNK kinases. Adaptation to hypoxia enhances HK-2 association with mitochondria and causes translocation of PKCD, PKC $B I$, and PKCn to the mitochondria. It has been shown that $\mathrm{PKCD}, \mathrm{PKC} \varepsilon$, ERK1/2, and MEK1/2 are involved in the cardioprotective effect of chronic hypoxia. The role of other kinases in the cardioprotective effect of adaptation to hypoxia requires further research.

\section{Key words}

Heart • Adaptation • Chronic hypoxia • Ischemia/reperfusion • Kinases

\section{Corresponding author}

Natalia V. Naryzhnaya, Principal Investigator of Laboratory Experimental Cardiology, Cardiology Research Institute, Tomsk National Research Medical Center, Russian Academy of Sciences, Kievskaya str, 111A, 634012, Russia. E-mail: natalynar@yandex.ru

\section{Introduction}

It is well known that adaptation to hypoxia increases resistance of the heart to ischemia/reperfusion (I/R) (Meerson et al. 1989, Kolar and Ostádal 2004, Gu et al. 2018, Tsibulnikov et al. 2018, Naryzhnaya et al. 2019, Prokudina et al. 2019). A cardioprotective effect has been observed in various models of chronic hypoxia. The most studied cardioprotective model has been that of intermittent hypobaric hypoxia (IHH), which partially mimics high altitude hypoxia and continuous normobaric hypoxia $(\mathrm{CNH})$, and there are many variations of this model; for example, IHH is modeled at altitudes of $5000 \mathrm{~m}$ (Li et al. 2016, Gu et al. 2018), $5500 \mathrm{~m}$ (Morel et al. 2003), 7000 m (Neckar et al. 2005, Hlaváčková et al. 2010), and even $7620 \mathrm{~m}$ (Nehra et al. 2016), while normobaric hypoxia is modeled for $\mathrm{O}_{2}$ contents of $8 \%$ (Viganò et al. 2011), $10 \%$ (Rafiee et al. 2002, Kolar et al. 2017, Zhao et al. 2008), and $12 \%$ (Tsibulnikov et al. 2018, Naryzhnaya et al. 2016, Prokudina et al. 2019), with and without reoxygenation periods.

The study of the mechanisms of cardioprotection that occur during chronic hypoxia, particularly the intracellular kinase mechanisms, has attracted the attention of numerous researchers. It has been established that kinases play an important role in regulating cardiac tolerance to $\mathrm{I} / \mathrm{R}$ (Heusch 2015, Yellon and Downey 2003). The activation of some kinases increases the resistance of the heart to I/R (Heusch 2015, Yellon and Downey 2003) while other kinases, in contrast, are involved in I/R heart damage (Milano et al. 2007, Ling 
et al. 2013). The kinase mechanism of protective action has been studied extensively in various pre- and postconditioning models (Heusch 2015). However, it is reasonable to believe that this mechanism is significantly different in chronic hypoxia, compared to that in the conditioning models. The expression and activity of many kinases in the myocardium are altered after various hypoxic effects (Table 1). This review analyzes published data on the role of kinases in implementing the infarctionlimiting effect of adaptation to hypoxia.

Table 1. The effect of chronic hypoxia on the expression of protein kinases in the myocardium

\begin{tabular}{|c|c|c|c|}
\hline The name of the kinases & Localization & Hypoxia model & Authors \\
\hline$P K C \varepsilon \uparrow, P K C \delta \uparrow$ & RV & IHH (5500 m, 23 h/day, 2 weeks) & Morel et al. 2003 \\
\hline$P K C \delta \uparrow$ & LV & $\begin{array}{c}\text { IHH (7000 m, } 8 \text { h/day, } 5 \text { days/week, } \\
\text { 24-32 exposure) }\end{array}$ & $\begin{array}{c}\text { Neckar et al. } 2005 \\
\text { Hlavackova et al. } 2007\end{array}$ \\
\hline$p-P K C \varepsilon \uparrow$ & LV & $\begin{array}{c}\text { IHH (7000 m, } 8 \text { h/day, } 5 \text { days/week, } \\
\text { 24-32 exposure) }\end{array}$ & Hlavackova et al. 2010 \\
\hline$P K C \alpha, p-P K C \alpha \uparrow$ & LV & IHH (7000 m, 8 h/day, 5 weeks) & Micova et al. 2016 \\
\hline$P K C \varepsilon \uparrow$ & LV & $\begin{array}{c}\mathrm{CNH}\left(\mathrm{SaO}_{2} 85 \%, 10 \text {-days, infant }\right. \\
\text { rabbit })\end{array}$ & Rafiee et al. 2002 \\
\hline$P K C \varepsilon \uparrow$ & $\mathrm{LV}$ & $\mathrm{CNH}\left(10 \% \mathrm{O}_{2}, 21\right.$ days $)$ & Holzerova et al. 2015 \\
\hline$A M P K \uparrow, p-A M P K \uparrow$ & $\begin{array}{l}\text { Total } \\
\text { LV }\end{array}$ & IHH (5000 m, 6 h/day 28 days) & $\begin{array}{l}\text { Li et al. } 2016 \\
\text { Gu et al. } 2018\end{array}$ \\
\hline$p-A M P K \downarrow$ & Total & $\begin{array}{c}\mathrm{INH}\left(8 \% \mathrm{O}_{2}, 120 \mathrm{~s}\right):(21 \%, 300 \mathrm{~s} .) \\
\text { cycles, } 8 \text { h/day, } 7 \text { days/week, } 10 \\
\text { weeks }\end{array}$ & Xie et al. 2016 \\
\hline$A M P K$ no effect & Total & $\mathrm{CNH}\left(18 \% \mathrm{O}_{2}, 24 \mathrm{~h}\right)$ & $\begin{array}{l}\text { Mohammed Abdul } \\
\text { et al. } 2015\end{array}$ \\
\hline$p-A M P K \uparrow$ & Total & $\mathrm{CNH}\left(48 \mathrm{~h}\right.$ at $\left.8 \% \mathrm{O}_{2}\right)$ & Viganò et al. 2011 \\
\hline$p-A M P K$ no effect & & $\mathrm{CNH}\left(10\right.$ days at $\left.8 \% \mathrm{O}_{2}\right)$ & \\
\hline$p-A M P K \downarrow$ & LV & $\mathrm{CNH}\left(10 \% \mathrm{O}_{2}, 21\right.$ days $)$ & Kolar et al. 2017 \\
\hline$p-A M P K \downarrow$ & RV & Cyanotic heart disease & Zhang et al. 2018 \\
\hline$C a M K I I \gamma \uparrow C a M K I I \delta \uparrow$ & Total & $\mathrm{CNH}\left(10 \% \mathrm{O}_{2}, 3\right.$ weeks $)$ & Zhao et al. 2008 \\
\hline CaMKII $\uparrow$ & RV & IHH (7620 m, 21 days) & Nehra et al. 2016 \\
\hline$E R K 2 \uparrow$ & RV & IHH (7000 m, 8 h/day, 25 exposures) & Strnisková et al. 2006 \\
\hline$p$-ERK2 no effect & $\mathrm{RV}, \mathrm{LV}$ & & \\
\hline$p-E R K 1 / 2 \uparrow$ & LV & IHH (7000 m, 8 h/day, 5 weeks) & Micova et al. 2016 \\
\hline$p-E R K 1 / 2 \uparrow$ to $C N H$ & $\mathrm{LV}$ & INH ( $10 \% \mathrm{O}_{2}, 2$ weeks $)$ & Milano et al. 2010 \\
\hline$p-E R K 1 / 2 \uparrow$ & Atriums & $\mathrm{INH}\left(8 \% \mathrm{O}_{2}, 6 \mathrm{~h} /\right.$ day, 30 days $)$ & Zhang et al. $2018 \mathrm{~b}$ \\
\hline$p-A k t \uparrow$ & LV & IHH (7000 m, 8 h/day, 25 exposures) & Strnisková et al. 2006 \\
\hline$p-A k t \uparrow$ to $C N H$ & LV & INH $\left(10 \% \mathrm{O}_{2}, 2\right.$ weeks $)$ & Milano et al. 2010 \\
\hline$p-A k t \uparrow$ & LV & $\mathrm{CNH}\left(10 \% \mathrm{O}_{2}, 21\right.$ days $)$ & Kolar et al. 2017 \\
\hline$P I 3 K \uparrow$ & Total & $\begin{array}{l}\text { INH ( } 4 \text { daily cycles, each composed } \\
\text { of } 2-\text { min at } 6-8 \% \mathrm{O}_{2} \text { followed by } 3- \\
\text { min reoxygenation for } 5 \text { times, for } 14 \\
\text { days) }\end{array}$ & Milano et al. 2013 \\
\hline$P I 3 K \downarrow, p-A k t \downarrow$ & RV & INH ( $8 \% \mathrm{O}_{2}, 6$ h/day, 30 days $)$ & Zhang et al. $2018 \mathrm{~b}$ \\
\hline PKA no effect & Total & $\mathrm{CNH}\left(10 \% \mathrm{O}_{2}, 14\right.$ days $)$ & Larsen et al. 2008 \\
\hline$P K A \uparrow$ & LV & IHH (7000 m, 8 h/day, 35 exposures) & Kohutova et al. 2019 \\
\hline
\end{tabular}


Table 1. (continued)

\begin{tabular}{|c|c|c|c|}
\hline The name of the kinases & Localization & Hypoxia model & Authors \\
\hline p38 no effect & $\mathrm{RV}, \mathrm{LV}$ & IHH (7000 m, 8 h/day, 35 exposures) & Strnisková et al. 2006 \\
\hline$p-p 38 \downarrow$ & RV & & \\
\hline$p-p 38 \uparrow$ & LV & & \\
\hline$p-p 38 \uparrow$ & LV & IHH (7000 m, 8 h/day, 5 weeks) & Micova et al. 2016 \\
\hline$p-p 38 \uparrow$ & LV & $\mathrm{CNH}\left(10 \% \mathrm{O}_{2}, 2\right.$ weeks $)$ & $\begin{array}{l}\text { Morel et al. } 2006 \text {, } \\
\text { Milano et al. } 2010\end{array}$ \\
\hline$p-p 38 \uparrow$ & RV & $\mathrm{CNH}$, cyanotic heart defects & Quing et al. 2007 \\
\hline$p$-JNK no effect & LV & $\mathrm{CNH}\left(10 \% \mathrm{O}_{2}, 2\right.$ weeks $)$ & Morel et al. 2006 \\
\hline$J N K$ particular fraction $\downarrow$ & LV & IHH (7000 m, 8 h/day, 25 exposures) & Strnisková et al. 2006 \\
\hline JNK particular fraction $\uparrow$ & RV & & \\
\hline$p-J N K \uparrow$ & $\mathrm{H}_{9} \mathrm{C}_{2}$ cells & Acute hypoxia $\left(1 \% \mathrm{O}_{2}, 12-72 \mathrm{~h}\right)$ & He et al. 2016 \\
\hline$p-J N K / J N K \uparrow$ & Total & $\begin{array}{l}\text { INH }\left(9 \% \mathrm{O}_{2}, 20 \text { times/h for } 8 \mathrm{~h} / \text { day, }\right. \\
35 \text { days })\end{array}$ & Zhao et al. 2019 \\
\hline$P K G$ & LV & IHH (7000m, 8 h/day, 35 exposures) & Kohutova et al. 2019 \\
\hline$H K-1 \uparrow, H K-2 \uparrow$ & LV & IHH (7000 m, 8 h/day, 5 weeks) & $\begin{array}{l}\text { Waskova-Arnostova et al. } \\
2015\end{array}$ \\
\hline$H K-1 \uparrow, H K-2 \uparrow$ & LV & $\mathrm{CNH}\left(10 \% \mathrm{O}_{2}, 3\right.$ weeks $)$ & Kolar et al. 2017 \\
\hline$H K-2 \uparrow$ & LV & $\mathrm{CNH}\left(10 \% \mathrm{O}_{2}, 3\right.$ weeks $)$ & Nedvedova et al. 2018 \\
\hline
\end{tabular}

$\mathrm{IHH}$ - intermittent hypobaric hypoxia, CNH - continuous normobaric hypoxia, INH - intermittent normobaric hypoxia, PKC - protein kinase C, AMPK - AMP-activated protein kinase, CaMKII - $\mathrm{Ca}^{2+}$-calmodulin kinase II, ERK - extracellular signal-regulated kinase, Akt Akt-kinase, PI3K - phosphatidylinositol-3-kinase, PKA - protein kinase A, p38 - p38-kinase, JNK - c-Jun N-terminal kinase, PKG protein kinase G, GSK3 $\beta$ - glycogen synthase kinase $3 \beta$, HK - hexokinase, LV - left ventricular, RV - right ventricular

\section{Protein kinase $\mathbf{C}$}

Protein kinase $\mathrm{C}$, commonly abbreviated as $\mathrm{PKC}$ (EC 2.7.11.13), is a family of protein kinase enzymes involved in controlling the function of several other proteins by phosphorylating the hydroxyl groups of the serine and threonine amino acid residues in them. PKC enzymes, in turn, are activated by signals such as increases in the concentration of diacylglycerol (DAG) or calcium ions $\left(\mathrm{Ca}^{2+}\right)$ (Endoh 1995). Hence, PKC enzymes play important roles in several signal transduction cascades, including the protective cascade of different types of conditioning (Okubo et al. 2003, Gao et al. 2013).

\section{Intermittent hypoxia}

In adult rats that were exposed to $\mathrm{IHH}, 23 \mathrm{~h} /$ day at a $5500 \mathrm{~m}$ simulated altitude with $1 \mathrm{~h}$ reoxygenation for 2 weeks, there was an increase in PKC $\delta$ and PKC $\varepsilon$ levels in the right myocardial ventricle (Morel et al. 2003). It has been found that the PKC $\delta$ protein level in the left ventricle of chronically hypoxic rats is elevated in more severe $\mathrm{IHH}$ (8h/day at a $7000 \mathrm{~m}$ simulated altitude, 5 days/week, 24-32 exposure, Neckar et al. 2005, Hlaváčková et al. 2010). In a study by Neckar, it was established that the infarction-reducing effect of $\mathrm{IHH}$ does not appear after PKC inhibition with chelerythrine and the selective PKC $\delta$ blocker rottlerin reduced, but did not eliminate, the infarction-limiting effect of $\mathrm{IHH}$ (Neckar et al. 2005). In a later study, it was found that the PKC $\delta$ level in the particulate fraction of the left ventricle negatively correlates with infarct size after adaptation to intermittent hypoxia under the same conditions (Hlavackova et al. 2007). At the same time, there is evidence that an increase in PKC $\delta$ activity could be the result of the oxidative stress observed after exposure to IHH. Thus, it has been found that daily administration of the antioxidant $\mathrm{N}$-acetylcysteine to rats eliminates the infarction-reducing effect of $\mathrm{IHH}$ and eliminates translocation of PKC $\delta$ to the particulate fraction (Kolar et al. 2007).

It has been found that IHH $(8 \mathrm{~h} /$ day, 5 weeks at a $7000 \mathrm{~m}$ simulated altitude) contributes to an increase in $\mathrm{PKC} \alpha$ expression and phosphorylation (activation) $\mathrm{p}-\mathrm{PKC} \alpha$ 
in the myocardium (Micova et al. 2016), as well as an increase in p-PKCE expression (Hlaváčková et al. 2010).

Notably, in transgenic murine (aPKC $\varepsilon$ ) hearts with constitutively active $\mathrm{PKC} \varepsilon$, a shift from fatty acid to glucose oxidation was observed after 14-days of hypobaric hypoxia and enhancement of mitochondrial respiration, when compared to wild type mice (McCarthy et al. 2011). After 14-days of exposure to hypobaric hypoxia, the protein levels of phospho-GSK3 $\beta$, PGC1 $\alpha$, and HIF- $1 \alpha$ were elevated in aPKC $\varepsilon$ mice.

It has been established that IHH increases cardiomyocyte resistance to anoxia/reoxygenation and reduces $\mathrm{Ca}^{2+}$ overload in cardiomyocytes after anoxia/reoxygenation, and the PKC inhibitor chelerythrine eliminates these protective effects (Ma et al. 2014).

\section{Continuous hypoxia}

After 10-days of exposure to normobaric hypoxia at $\mathrm{SaO}_{2} 85 \%$, translocation (activation) of PKCE to the particulate fraction has been reported in the right ventricle of infants with cyanotic heart defects and in both ventricles of newborn rabbits (Rafiee et al. 2002). It has also been found that $\mathrm{CNH}\left(10 \% \mathrm{O}_{2}, 21\right.$ days) promotes an increase in $\mathrm{PKC} \varepsilon$ expression and its content in the particulate fraction of the left ventricle homogenates (Holzerova et al. 2015). Thus, $\mathrm{CNH}$ induced the translocation of $\mathrm{PKC} \varepsilon$ to the mitochondria and nucleus of cells. The selective inhibitor PKC $\varepsilon$ KP-1633 eliminated the cytoprotective effect of chronic hypoxia (Holzerova et al. 2015).

Afterward, we found that chelerythrine eliminates the infarct-sparing effect of $\mathrm{CNH}\left(12 \% \mathrm{O}_{2}\right.$, 21 days) (Tsibulnikov et al. 2018), and both chelerythrine and rottlerin eliminate an adaptive increase in cardiomyocyte tolerance to anoxia/reoxygenation under the same hypoxic training (Naryzhnaya et al. 2016).

Although rats subjected to more severe $\mathrm{CNH}$ $\left(\begin{array}{lllll}10 \% & \mathrm{O}_{2} & \text { for } & 3-7 & \text { days }) \\ \text { contributed to altered }\end{array}\right.$ translocation of PKC $\delta$ from the cytosol to the particular fraction in the right ventricle, the translocation of PKC $\beta$ II and $\mathrm{PKC} \eta$ increased in the left ventricle at 14-21 days of this hypoxic condition (Zeng et al. 2017).

The presented data convincingly indicates the involvement of PKC $\delta$ and $\mathrm{PKC} \varepsilon$ in the cardioprotective effect of both chronic hypoxia regimes; however, at least with regard to continuous hypoxia, the changes in PKC disappeared with more severe hypoxic exposure.

\section{AMPK kinase}

AMPK or 5' adenosine monophosphate-activated protein kinase is the enzyme (EC 2.7.11.31), which plays a role in cellular energy homeostasis, largely to activate glucose and fatty acid uptake and oxidation when cellular energy is low. It is involved in the cardioprotective effects of preconditioning (Khaliulin et al. 2007) and postconditioning (Hermann et al. 2012).

\section{Intermittent hypoxia}

It has been shown that IHH $(5,000 \mathrm{~m}$ for 28 days, $6 \mathrm{~h} /$ day) contributed to an increase in the p-AMPK level in the left myocardial ventricle ( $\mathrm{Li}$ et al. 2016) and in isolated left ventricular cardiomyocytes (Gu et al. 2018).

However, it has been demonstrated a decrease in the $\mathrm{p}$-AMPK level in the myocardium of rats subjected to severe intermittent normobaric hypoxia ( $\mathrm{INH}, 8 \% \mathrm{O}_{2}$, $120 \mathrm{~s}: 21 \%, 300 \mathrm{~s}$. cycles, $8 \mathrm{~h} /$ day, 7 days/week, 10 weeks) (Xie et al. 2016).

\section{Continuous hypoxia}

Short-term moderate CNH $\left(24 \mathrm{~h}, 18 \% \mathrm{O}_{2}\right)$ does not induce a change in AMPK content in myocardial tissue (Mohammed Abdul et al. 2015). Moreover, the authors report on the infarction-limiting effect of this regimen of adaptation to hypoxia. Acute normobaric hypoxia lasting $48 \mathrm{~h}$ at $8 \% \mathrm{O}_{2}$ in mice causes an increase in the p-AMPK (activated AMPK) level, but chronic continuous hypoxia - 10 days at $8 \% \mathrm{O}_{2}$ - does not cause such significant changes (Viganò et al. 2011). Chronic continuous hypoxia $\left(10 \% \mathrm{O}_{2} 21\right.$ days) causes a decrease in the p-AMPK level in the rat left ventricle during ischemia, but there are no differences after the reperfusion phase (Kolar et al. 2017). Contrary in the myocardium of patients with congenital heart disease, which corresponds to severe hypoxic conditions, the amount of p-AMPK was higher than that in patients with acyanotic heart disease (Zhang et al. 2018a).

These data showed positive changes in AMPK at moderate intermittent hypoxia and downregulation of AMPK under continuous severe intermittent hypoxia. It should be noted that there is no data on the elimination of the cardioprotective effect of chronic hypoxia by AMPK blockers. There is no evidence that a decrease or an increase in AMPK phosphorylation is associated with cardioprotection in conditions of chronic hypoxia. Therefore, we cannot evaluate the role of this kinase. 


\section{CaMKII kinase}

$\mathrm{Ca}^{2+} /$ calmodulin-dependent protein kinase II (CaM kinase II or CaMKII, EC 2.7.11.17) is a serine/threonine-specific protein kinase that is regulated by the $\mathrm{Ca}^{2+} /$ calmodulin complex. CaMKII is necessary for $\mathrm{Ca}^{2+}$ homeostasis and reuptake in cardiomyocytes (Anderson 2005).

It is known that the activation of $\mathrm{Ca}^{2+}$-calmodulin kinase II (CaMKII kinase) exacerbates I/R injury of the heart (Ling et al. 2013). It has been found that the expression of mRNA encoding calmodulin, CaMKII $\gamma$, and $\mathrm{CaMKII} \delta$ in the rat myocardium was enhanced after exposure to severe continuous hypoxia $\left(10 \% \mathrm{O}_{2}\right.$, 3 weeks) (Zhao et al. 2008). An increased CaMKII expression in the right ventricle after exposure to severe IHH at $7620 \mathrm{~m}$ (21 days) was noted by other investigators (Nehra et al. 2016). Cardioprotection under chronic hypoxia has not been identified in the last two articles. However, under mild IHH (5000 m, 6 h/day, 6 week) preservation of contractility function and cardioprotection under $\mathrm{Ca}^{2+}$ overload depended on increased CaMKII expression, because a selective CaMKII inhibitor KN93 prevented protection (Xie et al. 2004). These data are the reason for a consideration of CaMKII as a candidate to one of regulating mechanisms at chronic hypoxia. However, after the course of chronic INH $\left(10 \% \mathrm{O}_{2}\right.$, $6 \mathrm{~h}$ /day, 7 days) elevated ${ }^{45} \mathrm{Ca}^{2+}$ uptake via sarcoplasmic reticulum $\mathrm{Ca}^{2+}$-ATPase (SERCA), release via ryanodine receptor (RyR) or extrusion by the $\mathrm{Na}^{+} / \mathrm{Ca}^{2+}$ exchanger (NCX) is not dependent on CaMKII (Yeung et al.2007).

\section{PI3 and protein kinase B/Akt kinase}

PI3Ks (EC 2.7.1-) are a family of related intracellular signal transducer enzymes capable of phosphorylating the 3 position hydroxyl group of the inositol ring of phosphatidylinositol. PI3K/AKT is an intracellular signaling pathway that is important in regulating the cell cycle. PI3K activation promotes phosphorylation and stimulation of AKT, localizing it in the plasma membrane (Mockridge et al. 2000). Protein kinase B/Akt kinase (AKT, EC 2.7.11-12), can have a number of downstream effects, such as activating mTOR (Jonassen et al. 2001) and largely involved in preconditioning phenomenon (Rossello et al. 2018).

It has been shown that IHH $(7000 \mathrm{~m}, 8 \mathrm{~h} /$ day, 25 exposures) causes an increase in p-Akt expression in the left ventricle of the rat heart (Strnisková et al. 2006).
It was established that the PI3K/Akt inhibitor LY294002 eliminates the infarction-limiting effect of $\mathrm{IHH}$ (Ravingerová et al. 2007).

In Milano's study (2013), it has been found that severe INH (4 daily cycles, each composed of 2-min at 6-8 $\% \mathrm{O}_{2}$ followed by 3-min reoxygenation for 5 times, for 14 days) contributes to the infarct-sparing effect and shows elevation of a p-Akt amount (Milano et al. 2013). The PI3-kinase inhibitor wortmannin eliminated the infarct-reducing effect of INH, as well as elevation of the level of HIF-1 $\alpha$ and Nrf2 transcription factors. However, other authors report that similar hypoxic conditioning $\mathrm{INH}$ - lead to a decrease in the PI3K and p-Akt levels in the rat right ventricle (Zhang et al. 2018b).

Severe $\mathrm{CNH}\left(10 \% \mathrm{O}_{2}, 2\right.$ weeks $)$ promotes an increase in a p-Akt amount (and a corresponding increase in the $\mathrm{p}-\mathrm{Akt} / \mathrm{Akt}$ ratio) in rat left ventricles only if daily $1 \mathrm{~h}$ reoxygenation was performed, but not in continuous hypoxia model (Milano et al. 2010). The Akt/PI3 kinase inhibitor LY-294002 abolished enhancement of contractility and decreased of infarct size caused by hypoxia/reoxygenation episodes compared to non-reoxygenated animals. In addition, it was shown important facts: Akt/PI3 inhibition by LY-294002 had no effect on the $\mathrm{p}-\mathrm{ERK}_{1 / 2} / \mathrm{ERK}_{1 / 2}$ ratio, but ERK1/2 inhibition by PD-98059 contributed to a decrease in the p-Akt/Akt ratio. These facts indicate that ERK1/2 is an upstream kinase with respect to Akt (Milano et al. 2010).

Milder continuous hypoxia without a reoxygenation phase $\left(\begin{array}{lllll}10 \% & \mathrm{O}_{2} & 21 & \text { days }\end{array}\right)$ causes an increase in the p-Akt level in the rat left ventricle (Kolar et al. 2017). However, we failed to confirm the involvement of PI3K in the infarct-limiting effect of similar hypoxic adaptation $\left(12 \% \mathrm{O}_{2}, \quad 21\right.$ days $)$ (Tsibulnikov et al. 2018). In addition, we found that PI3K blockade by wortmannin does not affect increased tolerance of isolated cardiomyocytes to anoxia/ reoxygenation in rats adapted for $\mathrm{CNH}$ (Naryzhnaya et al. 2016). Thus, the role of PI3K and Akt in the cardioprotective effect of chronic hypoxia is controversial.

\section{MEK and ERK kinases}

The mitogen-activated protein kinases (the MAPK/ERK kinases; MKKs or MEKs; EC 2.7.11.24) and subsequent downstream kinase Extracellular signalRegulated Kinases (ERKs, EC 2.7.11.24) are widely 
expressed protein kinase. These kinases are intracellular signaling molecules that are involved in functions including the regulation of meiosis, mitosis, and postmitotic functions in differentiated cells. Many different stimuli, including growth factors, cytokines, ligands for heterotrimeric G- protein-coupled receptors, transforming agents activate the MEK/ERK pathway (Sugden and Clerk 1997). It is known that these kinases are involved in cardioprotection at ischemic preconditioning (Rossello et al. 2018).

It has been established that chronic IHH (7000 m, $8 \mathrm{~h}$ /day, 25 exposures) contributes to an increase in ERK2 expression in the right, but not left myocardium ventricle (Strnisková et al. 2006). However, it was not found phosphorylation (activation) of ERK2 in both ventricles. Other investigators demonstrated increased phosphorylation of p-ERK1/2 in the myocardium at IHH in the same conditions (Micova et al. 2016). In addition, an increase in the p-ERK $1 / 2$ level has been found in rat atrium after INH performed in severe hypoxia $\left(6 \mathrm{~h} /\right.$ day for 30 days $\left.8 \% \mathrm{O}_{2}\right)$ (Zhang et al. 2018b).

It was established that excessive chronic $\mathrm{CNH}$ (two weeks, $10 \% \mathrm{O}_{2}$ ) exacerbates reperfusion myocardial contractility dysfunction of the isolated heart model and increases infarct size (Milano et al. 2010). However, if a similar hypoxia was modeled with daily periods of reoxygenation, this negative effect was avoided; there was no a reduction in contractility and an increase in infarct size. This method of modeling chronic hypoxia, an increase in phosphorylated ERK1/2 (p-ERK1/2) content in the myocardium was noted, and inhibition of ERK1/2 PD-98059 or MEK1/2 U0126 prevented the protective effect of reoxygenation episodes (Milano et al. 2010). These data suggest that ERK and MEK are involved in cardioprotection at chronic hypoxia.

\section{P38 kinase}

The p38 mitogen-activated protein kinases (EC 2.7.11.24) are a class of the mitogen-activated protein kinases (MAPKs) that are responsive to stress stimuli, such as cytokines, ultraviolet irradiation, heat shock, and osmotic shock, and are involved in cell differentiation, apoptosis and autophagy (Liu et al. 2015). Phosphorylation of p38 kinase is necessary to realize cardioprotection due to ischemic preconditioning (Weinbrenner et al. 1997) and postconditioning (Sun et al. 2006).
According to Strnisková's data (Strnisková et al. 2006), after IHH (7000 m, $8 \mathrm{~h} /$ day, 35 exposures) the total p38 level does not change in both ventricles. The p-p38 level in the right ventricle was reduced, and was elevated in the left ventricle. An increase in the p-p38 level in the myocardium of the left ventricle after IHH was noted in a later study (Micova et al. 2016).

It has been established that $\mathrm{CNH}$ (two weeks, $10 \% \mathrm{O}_{2}$ ) causes an increase in the p-p38 kinase level in the myocardium (Morel et al. 2006, Milano et al. 2010). Normobaric hypoxia with daily reoxygenation did not have a similar effect (Morel et al. 2006, Milano et al. 2010). In these studies, it was observed negative inotropic effect of $\mathrm{CNH}$ and enlarged of infarct size, which are prevented by the p-38 kinase inhibitors SB203580 or SB202190 (Morel et al. 2006). It was shown that the p-p38 level is increased in the myocardium of infants with cyanotic heart defects, but not in patients with acyanotic heart defects (Rafiee et al. 2002, Quing et al. 2007). However, in a study of the isolated heart of neonatal rabbit it was established that blocking p38 with SB203580 eliminates the cardioprotective effect of $\mathrm{CNH}$ (Rafiee et al. 2002). This is the only article about a positive role of p-p38 in the cardioprotective effect of chronic hypoxia.

\section{JNK kinase}

The c-Jun N-terminal kinases (JNKs, CE 2.7.11.24) were originally identified as the kinases that bind and phosphorylate c-Jun on Ser-63 and Ser-73 within its transcriptional activation domain. They belong to the mitogen-activated protein kinase family and are responsive to stress stimuli, such as cytokines, ultraviolet irradiation, heat shock, and osmotic shock. It is generally accepted that JNK plays a negative role in the regulation of cardiac tolerance to I/R (Milano et al. 2007). However, there is evidence that this enzyme is involved in the cardioprotective effect of remote preconditioning (Heidbreder et al. 2008).

Changes in the total JNK and p-JNK levels were not detected in the right and left ventricles of rats adapted for IHH (IHH 7000 m, 8 h/day, 35 exposures); however, it has been found that JNK content in the particulate fraction of the right ventricle was increased, but decreased in the particulate fraction of the left ventricles (Strnisková et al. 2006). It has been established that INH contributes to an increase in the $\mathrm{p}-\mathrm{JNK} / \mathrm{JNK}$ ratio in the myocardium (Zhao et al. 2019). 
It has been found that curcumin, a JNK inhibitor, eliminates the cardioprotective effect of $\mathrm{CNH}$ in rabbit infants (Rafiee et al. 2002). However, an increase in the p-JNK level has not been found in the left ventricle of adult rats after $\mathrm{CNH}$ (Morel et al. 2006), as it was shown at cell $\mathrm{H}_{9} \mathrm{C}_{2}$ culture (He et al. 2016). The presented data indicate that chronic hypoxia could promote an increase in the active $\mathrm{p}-\mathrm{JNK}$ level in the myocardium. At the same time, data on the involvement of this kinase in the cardioprotective effect of adaptation is limited to one study so far (Rafiee et al. 2002). Therefore, the role of JNK in the protective effect of chronic hypoxia remains to be elucidated.

\section{Protein kinase A}

Protein kinase A is a family of enzymes whose activity is dependent on cellular levels of cyclic AMP (cAMP). PKA is also known as cAMP-dependent protein kinase (EC 2.7.11.11). Protein kinase A has several functions in the cell, including regulation of glycogen, sugar, and lipid metabolism. This kinase is activated in $\beta$-adrenergic receptor agonists induced preconditioning (Robinet et al. 2005) and pharmacological preconditioning, but not in ischemic preconditioning (Lange et al. 2006).

At IHH (7000 m, 8 h/day, 35 exposures) PKA expression was increased in left ventricular myocardium (Kohutova et al. 2019).

In mice which were exposed to $\mathrm{CNH}\left(10 \% \mathrm{O}_{2}\right.$, 14 days), change in PKA isoforms' amount in left and right heart ventricle was not detected, as well as the total number of $\beta$-adrenergic receptors and adenylyl cyclase activity (Larsen et al. 2008). However, this is so far the only work in which the effect of $\mathrm{CNH}$ on the PKA level has been evaluated.

Therefore, it is too early to conclude a role of PKA in the cardioprotective effect of adaptation to hypoxia.

\section{Protein kinase G}

Protein kinase G (PKG, EC 2.7.11.12) or cGMPdependent protein kinase is a serine/threonine-specific protein kinase that is activated by cGMP. Protein kinase $\mathrm{G}$ type I (PKGI) is involved in survival signaling of preconditioning (Heusch 2015) and postconditioning (Inserte et al. 2013).

It has been found that IHH (7620 m, 21 days) causes an increase in the level of cGMP, PKG activator, in the myocardium (Nehra et al. 2016). In a later study it has been found an increase in PKG expression in the left ventricular myocardium at IHH $(7000 \mathrm{~m}, 8 \mathrm{~h} /$ day, 35 exposures) (Kohutova et al. 2019). It is not known what is a role of this kinase in the infarction-limiting effect of chronic hypoxia.

\section{Hexokinase}

Hexokinase (HK, EC 2.7.1.1) is the enzyme that phosphorylates hexoses (six-carbon sugars), forming hexose phosphate. Hexokinase 1 and 2 in cardiomyocytes are associated with voltage-dependent anion channel (VDAC) in the outer mitochondrial membrane (ShoshanBarmatz et al. 2009) and involved in the regulation of mitochondrial permeability transition pore (mPTP) opening (Tanaka et al. 2018). It is believed that the binding of hexokinase 2 (HK-2) to the mitochondria prevents apoptosis of cardiomyocytes (Majewski et al. 2004). It has been established that IHH (7000 m, 8 h/day, $5 \mathrm{wk}$ ) causes an increase in HK-1 and HK-2 expression in the myocardium and enhancement of translocation of hexokinase to the mitochondria (Waskova-Arnostova et al. 2015). CNH also increased HK-1 and HK-2 expression in the myocardium, enhanced the association of HK-2 with the mitochondria (Kolar et al. 2017). Similar effects of CNH were in SHR rats (Nedvedova et al. 2018). These findings are agreed with our results indicated on the stability of MPTP to opening inducing by I/R of the heart after CNH (Prokudina et al. 2019).

\section{Conclusion}

This study is devoted to an analysis of published data on the role of kinases in implementing the cardioprotective effect of adaptation to hypoxia (Fig. 1). It has been established that chronic intermittent hypoxia promotes increased expression of the following kinases in the myocardium: PKC $\delta, P K C \alpha, \mathrm{p}-\mathrm{PKC} \varepsilon, \mathrm{p}-\mathrm{PKC} \alpha$, AMPK, p-AMPK, CaMKII, p-ERK1/2, p-Akt, PI3-kinase, p-p38, HK-1, and HK-2.

Chronic continuous hypoxia contributes to increased expression of the following kinases in the myocardium: PKCe, PKC $3 \mathrm{II}, \mathrm{PKC \eta}, \mathrm{CaMKII}$, p-ERK1/2, p-Akt, p-p38, HK-1, and HK-2. However, enhanced expression of the AMPK and JNK kinases has not been detected.

Adaptation to hypoxia enhances the association 
of $\mathrm{HK}-2$ with the mitochondria and causes translocation of $\mathrm{PKC} \delta$, PKC $\beta I I$, and $\mathrm{PKC \eta}$ to the mitochondria. It has been proven that $\mathrm{PKC} \delta, \mathrm{PKC} \varepsilon, \mathrm{ERK} 1 / 2$, and MEK1/2 are involved in the cardioprotective effect of chronic hypoxia. The role of other kinases in the cardioprotective effect of adaptation to hypoxia requires further research. Possible relationships between the listed kinases have been studied in several works (Fig. 1). Thus, it has been found that chelerythrine significantly inhibits the translocation of both PKCE and p38 MAPK from the cytosolic to the particulate fraction in hypoxic rabbit heart, but p38 blockade does not alter PKCE phosphorylation (Rafiee et al. 2002). These data establish a relationship between $\mathrm{PKC}$ and $\mathrm{p} 38$ under continuous hypoxia. Inhibition of Akt/PI3 by LY-294002 did not affect the p-ERK1/2/ERK1/2 ratio, but inhibition of ERK1/2 by PD-98059 promoted a decrease in the p-Akt/Akt ratio under intermittent hypoxia (Milano et al. 2010). These facts indicate that ERK $1 / 2$ is an upstream kinase in relation to Akt.
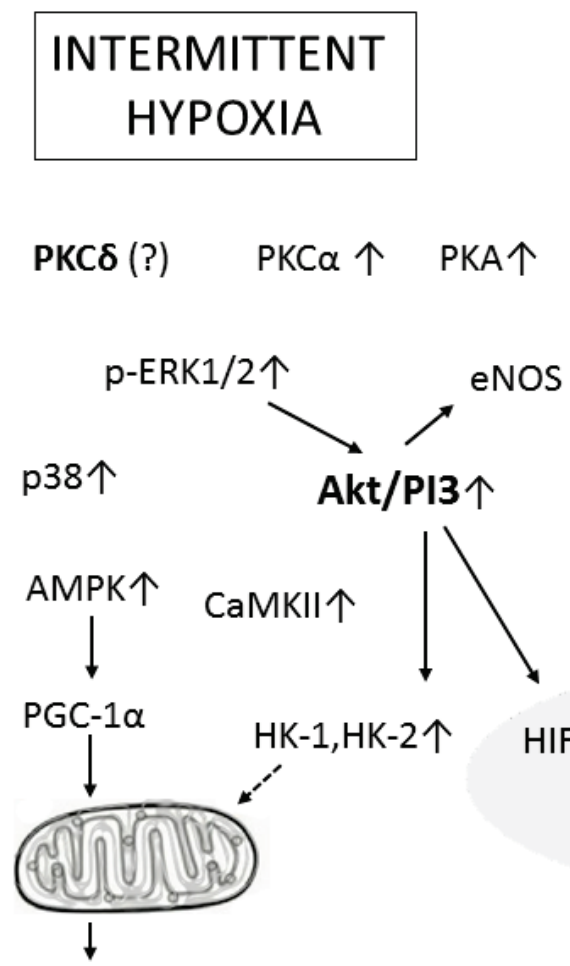

\section{CARDIAC TOLERANCE TO ISCHEMIA/REPERFUSION}

Fig. 1. Involvement of kinases in the cardioprotective effect of chronic hypoxia.

SUR2A - KATP channels regulatory subunits, MEK1/2 - mitogen-activated protein kinase kinase, ERK1/2 - extracellular signal-regulated kinase, PKC - protein kinase C, PKA - protein kinase A, PGC1a - peroxisome proliferator-activated receptor- $\gamma$ coactivator 1-a, JNK c-Jun N-terminal kinase, p38 - p38 kinase, PI3K - phosphatidylinositol-3-kinase, Akt - Akt kinase, CaMKII - Ca ${ }^{2+}$-calmodulin kinase II, HK - hexokinase, HSP70 - heat shock protein 70, HIF1a - hypoxia induced factor 1a, Nrf2 - nuclear factor-E2-related factor 2, ATF 2,6 - activating transcription factors 2 and 6 . Bold type indicates kinases, the inhibition of which leads to the elimination of the infarction-limiting effect of chronic hypoxia.

Protection corresponding to activation of kinases may be developed through any of the studied pathway (Fig. 1). Thus, the relationship between p38-kinase and the activation of transcription factor ATF6 was established under continuous hypoxia (Rafiee et al. 2002). Activation of HIF-1 $\alpha$ and Nrf2 transcription factors after INH is depended on PI3-kinase (Milano et al. 2013). A relationship was also established between
AKT and the sarcolemmal $\mathrm{K}_{\mathrm{ATP}}$ channel, and the PI3K inhibitor prevented an increase in subunit SUR2A expression in the left ventricle during normobaric hypoxia (Mohammed Abdul, et al. 2015). It was established that activation of AMPK promoted peroxisome proliferator-activated receptor- $\gamma$ coactivator $1-\alpha$ (PGC-1 $\alpha$ ) expression, which is involved in the cytoprotective effect of chronic hypoxia (Gu et al. 2018). 
The PI3-kinase inhibitor wortmannin prevented endothelial NO-synthase (eNOS) phosphorylation in cardiomyocytes under intermittent hypoxia (4 daily cycles, each composed of 2-min at 6-8 \% $\mathrm{O}_{2}$ followed by 3-min reoxygenation for 5 times, for 14 days), (Milano et al. 2013). Activation of eNOS and enhancement of NO synthesis may prevent endothelial dysfunction during reperfusion.

The present data eloquently suggests that the study of the mechanisms cardioprotection formation in chronic hypoxia needs further development.

\section{Acknowledgements}

The authors are grateful for the technical support of Nikita S. Voronkov.

The work was supported by the Russian Science Foundation, Grant 16-15-10001. Section devoted to PKA and $\mathrm{PKG}$, is carried out within the framework of state task AAAA-A15-115120910024-0

\section{Conflict of Interest}

There is no conflict of interest.

\section{References}

ANDERSON M: Calmodulin kinase signaling in heart: an intriguing candidate target for therapy of myocardial dysfunction and arrhythmias. Pharmacol Ther 106: 39-55, 2005. https://doi.org/10.1016/j.pharmthera.2004.11.002

ENDOH M: The effects of various drugs on the myocardial inotropic response. Gen Pharmacol 26: 1-31, 1995. https://doi.org/10.1016/0306-3623(94)00144-C

GAO Q, HU J, HU J, YU Y, YE H, LI Z, GUAN S: Calcium activated potassium channel and protein kinase C participate in the cardiac protection of remote post conditioning. Pak J Pharm Sci 26:285-90, 2013.

GU S, HUA H, GUO X, JIA Z, ZHANG Y, MASLOV LN, ZHANG X, MA H: PGC-1 $\alpha$ participates in the protective effect of chronic intermittent hypobaric hypoxia on cardiomyocytes. Cell Physiol Biochem 50: 1891-1902, 2018. https://doi.org/10.1159/000494869

HE S, LIU S, WU X, XIN M, DING S, XIN D, OUYANG H, ZHANG J: Protective role of downregulated MLK3 in myocardial adaptation to chronic hypoxia. J Physiol Biochem 73: 371-380, 2016. https://doi.org/10.1007/s13105-017-0561-5

HEIDBREDER M, NAUMANN A, TEMPEL K, DOMINIAK P, DENDORFER A: Remote vs. ischaemic preconditioning: the differential role of mitogen-activated protein kinase pathways. Cardiovasc Res 78: 108115, 2008. https://doi.org/10.1093/cvr/cvm114

HERMANN R, MARINA PRENDES MG, TORRESIN ME, VÉLEZ D, SAVINO EA, VARELA A: Effects of the AMP-activated protein kinase inhibitor compound $\mathrm{C}$ on the postconditioned rat heart. J Physiol Sci 62: 333-341, 2012. https://doi.org/10.1007/s12576-012-0209-8

HEUSCH G: Molecular basis of cardioprotection: signal transduction in ischemic pre-, post-, and remote conditioning. Circ Res 116: 674-699, 2015. https://doi.org/10.1161/CIRCRESAHA.116.305348

HLAVÁČKOVÁ M, KOŽICHOVÁ K, NECKÁŘ J, KOLÁŘ F, MUSTERS RJ, NOVÁK F, NOVÁKOVÁ O: Upregulation and redistribution of protein kinase $\mathrm{C}-\delta$ in chronically hypoxic heart. Mol Cell Biochem 345: 271-282, 2010. https://doi.org/10.1007/s11010-010-0581-8

HLAVÁČKOVÁ M, NECKÁR J, JEZKOVÁ J, BALKOVÁ P, STANKOVÁ B, NOVÁKOVÁ O, KOLÁR F, NOVÁK F: Dietary polyunsaturated fatty acids alter myocardial protein kinase $\mathrm{C}$ expression and affect cardioprotection induced by chronic hypoxia. Exp Biol Med (Maywood) 232: 823-832, 2007.

HOLZEROVA K, HLAVÁČKOVÁ M, ŽURMANOVÁ J, BORCHERT G, NECKÁŘ J, KOLÁR̆ F, NOVÁK F, NOVÁKOVÁ O: Involvement of PKCE in cardioprotection induced by adaptation to chronic continuous hypoxia. Physiol Res 64: 191-201, 2015. https://doi.org/10.33549/physiolres.932860

INSERTE J, HERNANDO V, VILARDOSA Ú, ABAD E, PONCELAS-NOZAL M, GARCIA-DORADO D: Activation of cGMP/protein kinase G pathway in postconditioned myocardium depends on reduced oxidative stress and preserved endothelial nitric oxide synthase coupling. J Am Heart Assoc 2:e005975, 2013. https://doi.org/10.1161/JAHA.112.005975 
JONASSEN AK, SACK MN, MJOS OD, YELLON DM: Myocardial protection by insulin at reperfusion requires early administration and is mediated via Akt and p70s6 kinase cell-survival signaling. Circ Res 89:1191-1198, 2001. https://doi.org/10.1161/hh2401.101385

KHALIULIN I, CLARKE SJ, LIN H, PARKER J, SULEIMAN MS, HALESTRAP AP: Temperature preconditioning of isolated rat hearts-a potent cardioprotective mechanism involving a reduction in oxidative stress and inhibition of the mitochondrial permeability transition pore. J Physiol 581: 1147-1161, 2007. https://doi.org/10.1113/jphysiol.2007.130369

KOHUTOVA J, ELSNICOVA B, HOLZEROVA K, NECKAR J, SEBESTA O, JEZKOVA J, VECKA M, VEBR P, HORNIKOVA D, SZEIFFOVA BACOVA B, EGAN BENOVA T, HLAVACKOVA M, TRIBULOVA N, KOLAR F, NOVAKOVA O AND ZURMANOVA JM: Anti-arrhythmic cardiac phenotype elicited by chronic intermittent hypoxia is associated with alterations in connexin-43 expression, phosphorylation, and distribution. Front Endocrinol (Lausanne) [Internet] 9: 1-10, 2019. https://doi.org/10.3389/fendo.2018.00789

KOLAR D, GRESIKOVA M, WASKOVA-ARNOSTOVA P, ELSNICOVA B, KOHUTOVA J, HORNIKOVA D, VEBR P, NECKAR J, BLAHOVA T, KASPAROVA D, NOVOTNY J, KOLAR F, NOVAKOVA O, ZURMANOVA JM: Adaptation to chronic continuous hypoxia potentiates Akt/HK2 anti-apoptotic pathway during brief myocardial ischemia/reperfusion insult. Mol Cell Biochem 432: 99-108, 2017. https://doi.org/10.1007/s11010-017-3001-5

KOLAR F, JEZKOVÁ J, BALKOVÁ P, BREH J, NECKÁR J, NOVÁK F, NOVÁKOVÁ O, TOMÁSOVÁ H, SRBOVÁ M, OST'ÁDAL B, WILHELM J, HERGET J: Role of oxidative stress in PKC- $\delta$ upregulation and cardioprotection induced by chronic intermittent hypoxia. Am J Physiol Heart Circ Physiol 292: H224-H230, 2007. https://doi.org/10.1152/ajpheart.00689.2006

KOLAR F, OSTÁDAL B: Molecular mechanisms of cardiac protection by adaptation to chronic hypoxia. Physiol Res 53: S3-13, 2004.

LANGE M, SMUL TM, BLOMEYER CA, REDEL A, KLOTZ KN, ROEWER N, KEHL F: Role of the beta1-adrenergic pathway in anesthetic and ischemic preconditioning against myocardial infarction in the rabbit heart in vivo. Anesthesiology 105: 503-510, 2006. https://doi.org/10.1097/00000542-200609000-00014

LARSEN KO, LYGREN B, SJAASTAD I, KROBERT KA, ARNKVAERN K, FLORHOLMEN G, LARSEN AK, LEVY FO, TASKÉN K, SKJØNSBERG OH, CHRISTENSEN G: Diastolic dysfunction in alveolar hypoxia: a role for interleukin-18-mediated increase in protein phosphatase 2A. Cardiovasc Res 80: 47-54, 2008. https://doi.org/10.1093/cvr/cvn180

LI X, LIU Y, MA H, GUAN Y, CAO Y, TIAN Y, ZHANG Y: Enhancement of glucose metabolism via PGC-1 $\alpha$ participates in the cardioprotection of chronic intermittent hypobaric hypoxia. Front Physiol 7: 1-8, 2016. https://doi.org/10.3389/fphys.2016.00219

LING H, GRAY CB, ZAMBON AC, GRIMM M, GU Y, DALTON N, PURCELL NH, PETERSON K, BROWN JH: CaMKII $\delta$ mediates myocardial ischemia/reperfusion injury through nuclear factor- $\kappa \mathrm{B}$. Circ Res 112: 935-944, 2013. https://doi.org/10.1161/CIRCRESAHA.112.276915

LIU J, CHANG F, LI F, FU H, WANG J, ZHANG S, ZHAO J, YIN D: Palmitate promotes autophagy and apoptosis through ROS-dependent JNK and p38 MAPK. Biochem Biophys Res Commun 463: 262-267, 2015. https://doi.org/10.1016/j.bbrc.2015.05.042

MA HJ, LI Q, MA HJ, GUAN Y, SHI M, YANG J, LI DP, ZHANG Y: Chronic intermittent hypobaric hypoxia ameliorates ischemia/reperfusion-induced calcium overload in heart via $\mathrm{Na}^{+} / \mathrm{Ca}^{2+}$ exchanger in developing rats. Cell Physiol Biochem 34: 313-324, 2014. https://doi.org/10.1159/000363001

MAJEWSKI N, NOGUEIRA V, BHASKAR P, COY PE, SKEEN JE, GOTTLOB K, CHANDEL NS, THOMPSON $\mathrm{CB}$, ROBEY RB, HAY N: Hexokinase-mitochondria interaction mediated by Akt is required to inhibit apoptosis in the presence or absence of Bax and Bak. Mol Cell16: 819-830, 2004. https://doi.org/10.1016/j.molcel.2004.11.014

MCCARTHY J, LOCHNER A, OPIE LH, SACK MN, ESSOP MF: PKCe promotes cardiac mitochondrial and metabolic adaptation to chronic hypobaric hypoxia by GSK3 $\beta$ inhibition. J Cell Physiol 226: 2457-2468, 2011. https://doi.org/10.1002/jcp.22592 
MEERSON FZ, USTINOVA EE, MANUKHINA EB: Prevention of cardiac arrhythmias by adaptation to hypoxia: regulatory mechanisms and cardiotropic effect. Biomed Biochim Acta 48: S83-S88, 1989.

MICOVA P, HAHNOVA K, HLAVACKOVA M, ELSNICOVA B, CHYTILOVA A, HOLZEROVA K, ZURMANOVA J, NECKAR J, KOLAR F, NOVAKOVA O, NOVOTNY J: Chronic intermittent hypoxia affects the cytosolic phospholipase A2 $\alpha /$ cyclooxygenase 2 pathway via $\beta 2$-adrenoceptor-mediated ERK/p38 stimulation. Mol Cell Biochem 423: 151-163, 2016. https://doi.org/10.1007/s11010-016-2833-8

MILANO G, MOREL S, BONNY C, SAMAJA M, VON SEGESSER LK, NICOD P, VASSALLI G: A peptide inhibitor of c-Jun NH2-terminal kinase reduces myocardial ischemia-reperfusion injury and infarct size in vivo. Am J Physiol Heart Circ Physiol 292: H1828-H1835, 2007. https://doi.org/10.1152/ajpheart.01117.2006

MILANO G, VON SEGESSER LK, MOREL S, JONCIC A, BIANCIARDI P, VASSALLI G, SAMAJA M: Phosphorylation of phosphatidylinositol-3-kinase-protein kinase B and extracellular signal-regulated kinases 1/2 mediate reoxygenation-induced cardioprotection during hypoxia. Exp Biol Med (Maywood) 235: 401-410, 2010. https://doi.org/10.1258/ebm.2009.009153

MILANO G, ABRUZZO PM, BOLOTTA A, MARINI M, TERRANEO L, RAVARA B, GORZA L, VITADELLO M, BURATTINI S, CURZI D, FALCIERI E, VON SEGESSER LK, SAMAJA M: Impact of the phosphatidylinositide 3-kinase signaling pathway on the cardioprotection induced by intermittent hypoxia. PLoS ONE 8: e76659, 2013. https://doi.org/10.1371/journal.pone.0076659

MOHAMMED ABDUL KS, JOVANOVIĆ S, DU Q, SUKHODUB A, JOVANOVIĆ A: Mild hypoxia in vivo regulates cardioprotective SUR2A: A role for Akt and LDH. Biochim Biophys Acta - Mol Basis Dis, 1852: 709-719, 2015. https://doi.org/10.1016/j.bbadis.2015.01.001

MOCKRIDGE JW, MARBER MS, HEADS RJ: Activation of Akt during simulated ischemia/reperfusion in cardiac myocytes. Biochem Biophys Res Commun 270: 947-952, 2000. https://doi.org/10.1006/bbrc.2000.2522

MOREL OE, BUVRY A, LE CORVOISIER P, TUAL L, FAVRET F, LEÓN-VELARDE F, CROZATIER B, RICHALET JP: Effects of nifedipine-induced pulmonary vasodilatation on cardiac receptors and protein kinase $\mathrm{C}$ isoforms in the chronically hypoxic rat. Pflugers Arch 446: 356-364, 2003. https://doi.org/10.1007/s00424-003-1034-y

MOREL S, MILANO G, LUDUNGE KM, CORNO AF, SAMAJA M, FLEURY S, BONNY C, KAPPENBERGER L, VON SEGESSER LK, VASSALLI G: Brief reoxygenation episodes during chronic hypoxia enhance posthypoxic recovery of LV function: role of mitogen-activated protein kinase signaling pathways. Basic Res Cardiol 101: 336-345, 2006. https://doi.org/10.1007/s00395-006-0596-1

NARYZHNAYA NV, KHALIULIN I, LISHMANOV YB, SULEIMAN MS, TSIBULNIKOV SY, KOLAR F, MASLOV LN: Participation of opioid receptors in the cytoprotective effect of chronic normobaric hypoxia. Physiol Res 68: 245-253, 2019. https://doi.org/10.33549/physiolres.933938

NARYZHNAYA NV, MASLOV LN, KHALIULIN IG, ZHANG Y, PEI JM, TSEPOKINA AV, KHUTORNAYA MV, KUTIKHIN AG, LISHMANOV YB: Chronic continuous normobaric hypoxia augments cell tolerance to anoxia/reoxygenation: the role of protein kinases. Ross Fiziol Zh Im I M Sechenova 102: 1462-1471, 2016.

NECKAR J, MARKOVÁ I, NOVÁK F, NOVÁKOVÁ O, SZÁRSZOI O, OST'ÁDAL B, KOLÁR F: Increased expression and altered subcellular distribution of $\mathrm{PKC}-\delta$ in chronically hypoxic rat myocardium: involvement in cardioprotection. Am J Physiol Heart Circ Physiol 288: H1566-H1572, 2005. https://doi.org/10.1152/ajpheart.00586.2004

NEDVEDOVA I, KOLAR D, ELSNICOVA B, HORNIKOVA D, NOVOTNY J, KALOUS M, PRAVENEC M, NECKAR J, KOLAR F, ZURMANOVA JM: Mitochondrial genome modulates myocardial Akt/Glut/HK salvage pathway in spontaneously hypertensive rats adapted to chronic hypoxia. Physiol Genomics 50: 532-541, 2018. https://doi.org/10.1152/physiolgenomics.00040.2017

NEHRA S, BHARDWAJ V, KAR S, SARASWAT D: Chronic hypobaric hypoxia induces right ventricular hypertrophy and apoptosis in rats: therapeutic potential of nanocurcumin in improving adaptation. High Alt Med Biol 17: 342-352, 2016. https://doi.org/10.1089/ham.2016.0032

OKUBO S, TANABE Y, FUJIOKA N, TAKEDA K, TAKEKOSHI N: Differential activation of protein kinase C between ischemic and pharmacological preconditioning in the rabbit heart. Jpn J Physiol 53: 173-80, 2003. https://doi.org/10.2170/jiphysiol.53.173 
PROKUDINA ES, NARYZHNAYA NV, MUKHOMEDZYANOV AV, GORBUNOV AS, ZHANG Y, YAGGI AS, TSIBULNIKOV SY, NESTEROV EA, LISHMANOV YB, SULEIMAN MS, OELTGEN PR, MASLOV LN: Effect of chronic continuous normobaric hypoxia on functional state of cardiac mitochondria and tolerance of isolated rat heart to ischemia and reperfusion: Role of $\mu$ and delta2. Physiol Res 30: 68: 909-920, 2019. https://doi.org/10.33549/physiolres.933945

QUING M, GÖRLACH A, SCHUMACHER K, WÖLTJE M, VAZQUEZ-JIMENEZ JF, HESS J, SEGHAYE MC: The hypoxia-inducible factor HIF-1 promotes intramyocardial expression of VEGF in infants with congenital cardiac defects. Basic Res Cardiol 102: 224-232, 2007. https://doi.org/10.1007/s00395-007-0639-2

RAFIEE P, SHI Y, KONG X, PRITCHARD KA, TWEDDELL JS, LITWIN SB, MUSSATTO K, JAQUISS RD, SU J, BAKER JE: Activation of protein kinases in chronically hypoxic infant human and rabbit hearts: role in cardioprotection. Circulation 106: 239-245, 2002. https://doi.org/10.1161/01.CIR.0000022018.68965.6D

RAVINGEROVÁ T, MATEJÍKOVÁ J, NECKÁR J, ANDELOVÁ E, KOLÁR F: Differential role of PI3K/Akt pathway in the infarct size limitation and antiarrhythmic protection in the rat heart. Mol Cell Biochem 297: 111-120, 2007. https://doi.org/10.1007/s11010-006-9335-Z

ROBINET A, HOIZEY G, MILLART H: PI 3-kinase, protein kinase C, and protein kinase A are involved in the trigger phase of betal-adrenergic preconditioning. Cardiovasc Res 66: 530-542, 2005. https://doi.org/10.1016/j.cardiores.2005.02.010

ROSSELLO X, RIQUELME JA, DAVIDSON SM, YELLON DM: Role of PI3K in myocardial ischaemic preconditioning: mapping pro-survival cascades at the trigger phase and at reperfusion. J Cell Mol Med 22:926-935, 2018. https://doi.org/10.1111/jcmm.13394

SHOSHAN-BARMATZ V, ZAKAR M, ROSENTHAL K, ABU-HAMAD S: Key regions of VDAC1 functioning in apoptosis induc- tion and regulation by hexokinase. Biochim Biophys Acta 1787: 421-430, 2009. https://doi.org/10.1016/j.bbabio.2008.11.009

STRNISKOVÁ M, RAVINGEROVÁ T, NECKÁR J, KOLÁR F, PASTOREKOVÁ S, BARANCÍK M: Changes in the expression and/or activation of regulatory proteins in rat hearts adapted to chronic hypoxia. Gen Physiol Biophys 25: 25-41, 2006.

SUN HY, WANG NP, HALKOS M, KERENDI F, KIN H, GUYTON RA, VINTEN-JOHANSEN J, ZHAO ZQ: Postconditioning attenuates cardiomyocyte apoptosis via inhibition of JNK and p38 mitogen-activated protein kinase signaling pathways. Apoptosis 11: 1583-1593, 2006. https://doi.org/10.1007/s10495-006-9037-8

SUGDEN PH, CLERK A: Regulation of the ERK subgroup of MAP kinase cascades through G protein-coupled receptors. Cell Signal 9:337-51, 1997. https://doi.org/10.1016/S0898-6568(96)00191-X

TANAKA T, SAOTOME M, KATOH H, SATOH T, HASAN P, OHTANI H, SATOH H, HAYASHI H, MAEKAWA Y: Glycogen synthase kinase-3 $\beta$ opens mitochondrial permeability transition pore through mitochondrial hexokinase II dissociation. J Physiol Sci 68: 865-871, 2018. https://doi.org/10.1007/s12576-018-0611-y

TSIBULNIKOV SY, MASLOV LN, NARYZHNAYA NV, MA H, LISHMANOV YB, OELTGEN PR, GARLID K: Role of protein kinase C, PI3 kinase, tyrosine kinases, NO-synthase, KATP channels and MPT pore in the signaling pathway of the cardioprotective effect of chronic continuous hypoxia. Gen Physiol Biophys 37: 537-547, 2018. https://doi.org/10.4149/gpb 2018013

VIGANÒ A, VASSO M, CARETTI A, BRAVATÀ V, TERRANEO L, FANIA C, CAPITANIO D, SAMAJA M, GELFI C: Protein modulation in mouse heart under acute and chronic hypoxia. Proteomics 11: 4202-4217, 2011. https://doi.org/10.1002/pmic.201000804

WASKOVA-ARNOSTOVA P, ELSNICOVA B, KASPAROVA D, HORNIKOVA D, KOLAR F, NOVOTNY J, ZURMANOVA J: Cardioprotective adaptation of rats to intermittent hypobaric hypoxia is accompanied by the increased association of hexokinase with mitochondria. J Appl Physiol (1985) 119: 1487-1493, 2015. https://doi.org/10.1152/japplphysiol.01035.2014

WEINBRENNER C, LIU GS, COHEN MV, DOWNEY JM: Phosphorylation of tyrosine 182 of p38 mitogen-activated protein kinase correlates with the protection of preconditioning in the rabbit heart. J Mol Cell Cardiol 29: 2383-91, 1997. https://doi.org/10.1006/jmcc.1997.0473 
XIE S, DENG Y, PAN Y, REN J, JIN M, WANG Y, WANG Z, ZHU D, GUO X, YUAN X, SHANG J, LIU H: Chronic intermittent hypoxia induces cardiac hypertrophy by impairing autophagy through the adenosine 5'-monophosphate-activated protein kinase pathway. Arch Biochem Biophys 606: 41-52, 2016. https://doi.org/10.1016/j.abb.2016.07.006

XIE Y, ZHU WZ, ZHU Y, CHEN L, ZHOU ZN, YANG HT: Intermittent high altitude hypoxia protects the heart against lethal $\mathrm{Ca}^{2+}$ overload injury. Life Sci 76: 559-772, 2004. https://doi.org/10.1016/j.lfs.2004.09.017

YELLON DM, DOWNEY JM: Preconditioning the myocardium: from cellular physiology to clinical cardiology. Physiol Rev 83: 1113-1151, 2003. https://doi.org/10.1152/physrev.00009.2003

YEUNG HM, KRAVTSOV GM, NG KM, WONG TM, FUNG ML: Chronic intermittent hypoxia alters Ca ${ }^{2+}$ handling in rat cardiomyocytes by augmented $\mathrm{Na}^{+} / \mathrm{Ca}^{2+}$ exchange and ryanodine receptor activities in ischemiareperfusion. Am J Physiol Cell Physiol 292: C2046-56, 2007. https://doi.org/10.1152/ajpcell.00458.2006

ZENG C, LIANG B, JIANG R, SHI Y, DU Y: Protein kinase C isozyme expression in right ventricular hypertrophy induced by pulmonary hypertension in chronically hypoxic rats. Mol Med Rep 16: 3833-3840, 2017. https://doi.org/10.3892/mmr.2017.7098

ZHANG H, LIU B, LI T, ZHU Y, LUO G, JIANG Y, TANG F, JIAN Z, XIAO Y: AMPK activation serves a critical role in mitochondria quality control via modulating mitophagy in the heart under chronic hypoxia. Int $\mathrm{J}$ Mol Med 41: 69-76, 2018a. https://doi.org/10.3892/ijmm.2017.3213

ZHANG K, MA Z, WANG W, LIU R, ZHANG Y, YUAN M, LI G: Beneficial effects of tolvaptan on atrial remodeling induced by chronic intermittent hypoxia in rats. Cardiovasc Ther 36: e12466, $2018 \mathrm{~b}$. https://doi.org/10.1111/1755-5922.12466

ZHAO PJ, PAN J, LI F, SUN K: Effects of chronic hypoxia on the expression of calmodulin and calcicum/calmodulindependent protein kinase II and the calcium activity in myocardial cells in young rats (In Chinese). Zhongguo Dang Dai Er Ke Za Zhi 10: 381-385, 2008.

ZHAO YS, AN JR, YANG S, GUAN P, YU FY, LI W, LI JR, GUO Y, SUN ZM, JI ES: Hydrogen and oxygen mixture to improve cardiac dysfunction and myocardial pathological changes induced by intermittent hypoxia in rats. Oxid Med Cell Longev 2019: 7415212, 2019. https://doi.org/10.1155/2019/7415212 